\title{
Primary Thromboprophylaxis in Children with Cancer: A Road Less Travelled
}

\author{
Chantal Attard ${ }^{1,2}$ Vera Ignjatovic ${ }^{1,2}$ \\ ${ }^{1}$ Haematology Research Laboratory, Murdoch Children's Research \\ Institute, Melbourne, Victoria, Australia \\ 2 Department of Paediatrics, The University of Melbourne, Melbourne, \\ Victoria, Australia
}

Thromb Haemost 2019;119:1894-1896.

The increased thrombotic risk for children and adults with cancer is well established, with many important studies undertaken in this field, particularly in the last 5 to 10 years. Studies published on this topic in Thrombosis and Haemostasis, over the past 2 years, have focused on identifying biomarkers associated with the risk of thromboembolism and mortality in patients with cancer ${ }^{1}$, as well as the effect of chemotherapy on thrombogenic properties of extracellular vesicles in the setting of breast cancer. ${ }^{2}$ Very recently, Carmona-Bayonas et al conducted a robust study in over 2,000 patients with advanced gastric cancer and described the use of multistate models for prediction of thrombotic risk in patients with cancer-associated thrombosis. ${ }^{3}$ This topic is of significant interest to clinicians worldwide.

When it comes to thromboprophylaxis in the setting of cancer, there is much debate around the timing and the choice of anticoagulants to be used. Balancing the risk of bleeding with the effectiveness of thromboprophylaxis strategies is not an easy task. This is particularly the case when choosing well-established strategies versus the non-vitamin $\mathrm{K}$ antagonist (VKA) oral anticoagulants (NOACs). Specific challenges associated with thromboprophylaxis in cancer patients were elegantly outlined and summarised in a 2018 review paper by Potpara and Poposka. ${ }^{4}$

While numerous studies in adults have presented overwhelming evidence for the benefits of thromboprophylaxis in the setting of cancer, the level of evidence and the consistency of findings is lacking for children. In fact, when it comes to children with cancer, thromboprophylaxis is not considered standard of care (SOC). The key consideration here is that adult evidence is not sufficient or appropriate when it comes to children, primarily due to developmental haemostasis but also due to the fact that the epidemiology of cancer is different in children compared with adults. Age-specific changes in the concentration, ${ }^{5}$ function ${ }^{6}$ and structure ${ }^{7}$ of haemostatic proteins as well as platelet phenotype ${ }^{8}$ and function ${ }^{9}$ are widely

received

October 4, 2019

accepted

October 4, 2019

Address for correspondence Vera Ignjatovic, PhD, Haematology Research Laboratory, Murdoch Children's Research Institute, 50 Flemington Road, Parkville, Victoria 3052, Australia (e-mail: vera.ignjatovic@mcri.edu.au).

known. Such differences in the haemostatic system between children and adults dictate that when treating children, in any setting, paediatric-specific evidence is required and that treating children like little adults is simply not appropriate. In fact, precision medicine as a practice is not possible without treating children as children and not as little adults.

When it comes to thromboprophylaxis strategies in children, let alone in children with cancer, important factors need to be considered and are outlined in - Table 1. For example, in addition to its anticoagulant properties, low molecular weight heparin (LMWH) is well known for its anti-angiogenic effects. ${ }^{10}$ In addition, the proportion of latent anti-thrombin (LAT), an anti-angiogenic form of anti-thrombin (AT), has been shown to be higher in adults compared with children. ${ }^{11}$ This begs the question of whether administering anti-angiogenic drugs to children, especially vulnerable children is appropriate. Is this what we want for our most vulnerable population?

In this issue of Thrombosis and Haemostasis, Pelland-Marcotte et al report a systematic review and meta-analysis that evaluates the effectiveness and safety of primary thromboprophylaxis in children with cancer. ${ }^{12}$ This network meta-analysis (allows multiple pairwise comparisons that combine direct and indirect evidence ${ }^{13}$ ) was designed to simultaneously compare AT replacement, LMWH, VKAs and SOC, which was defined as no thromboprophylaxis or low-dose heparin used exclusively for catheter patency. A total of six studies matched inclusion criteria (e.g., randomised controlled trials, prospective cohort studies and experimental studies without randomisation) and the majority of those were performed in the setting of acute lymphoblastic leukaemia (ALL). The main finding of this study is that low-dose LMWH is the only option identified as effective and safe to prevent thromboembolism in children with cancer and could in fact prevent $75 \%$ of thromboembolic events in this setting. The incidence of thromboembolic events was $8 \%$, which is consistent with findings to date ${ }^{14}$ and major bleeding

(c) 2019 Georg Thieme Verlag KG Stuttgart · New York
DOI https://doi.org/ $10.1055 / \mathrm{s}-0039-3400288$. ISSN 0340-6245. 
Table 1 Thromboprophylaxis approaches and paediatric-specific considerations

\begin{tabular}{|c|c|c|c|}
\hline Thromboprophylaxis & Advantage & Disadvantage & Paediatric-specific considerations \\
\hline UFH & $\begin{array}{l}\text { Reversible } \\
\text { Low cost }\end{array}$ & $\begin{array}{l}\text { Intravenous administration } \\
\text { Narrow therapeutic } \\
\text { window = frequent monitoring } \\
\text { Non-specific binding } \\
\text { to numerous plasma proteins }\end{array}$ & \multirow{5}{*}{$\begin{array}{l}\text { Epidemiology of cancer different to adults } \\
\text { Epidemiology of thrombosis different to adults } \\
\text { Concentration, activity and structure of haemostatic } \\
\text { proteins different to adults } \\
\text { Phenotype and function of platelets different } \\
\text { to adults } \\
\text { PK of UFH (and likely other drugs) different to adults } \\
\text { Self-administration is difficult or impossible }\end{array}$} \\
\hline LMWH & $\begin{array}{l}\text { Higher bioavailability, } \\
\text { predictable PK } \\
\text { profile and longer half-life } \\
\text { compared with UFH } \\
\text { Reduced monitoring } \\
\text { requirements } \\
\text { Anti-tumour effect? } \\
\text { Low cost }\end{array}$ & $\begin{array}{l}\text { Subcutaneous administration } \\
\text { Cannot be reversed }\end{array}$ & \\
\hline AT replacement & $\begin{array}{l}\text { Replacement of } \\
\text { physiological protein }\end{array}$ & $\begin{array}{l}\text { Intravenous administration } \\
\text { Expensive } \\
\text { Unproven benefit } \\
\text { Many studies suggest harm }\end{array}$ & \\
\hline $\begin{array}{l}\text { Vitamin K } \\
\text { antagonists }\end{array}$ & $\begin{array}{l}\text { Oral administration } \\
\text { Low cost } \\
\text { Reversible }\end{array}$ & $\begin{array}{l}\text { Narrow therapeutic } \\
\text { window = frequent monitoring } \\
\text { Impacted by concomitant } \\
\text { illness, other medications, } \\
\text { diet, vomiting, diarrhoea }\end{array}$ & \\
\hline Apixaban & $\begin{array}{l}\text { Oral administration } \\
\text { Predictable PK and PD } \\
\text { Wide therapeutic window } \\
\text { No need for } \\
\text { laboratory monitoring }\end{array}$ & $\begin{array}{l}\text { Cannot be reversed } \\
\text { High cost }\end{array}$ & \\
\hline
\end{tabular}

Abbreviations: AT, anti-thrombin; LMWH, low molecular weight heparin; PD, pharmacodynamics; UFH, unfractionated heparin.

occurred in $0.7 \%$ of the patients. Surprisingly, there were no studies that evaluated the effectiveness or safety of anti-platelet agents and unfractionated heparin. While three of the six studies were randomised open-label studies, no study blinded the subjects to their intervention group. Considering the debate surrounding AT replacement in children, the finding of decreased event-free survival in children who received AT is crucial evidence for the need for a serious consideration to be placed on any further use of AT in children with cancer. Importantly, the Pelland-Marcotte paper outlines the importance of LAT in this setting and that "repetitive use of AT concentrates as thromboprophylaxis modality could conceivably cause a disequilibrium of the angiogenic factors in patients with ALL." The high risk-to-benefit ratio of AT concentrates in the setting of children with cancer must be taken seriously. This study clearly outlines the possible limitations that need to be considered, nonetheless the findings are clinically meaningful and in the context of available evidence, and in taking the road less travelled, this study leads the way when considering whether and/if which thromboprophylaxis approaches could be useful in children with cancer.

Where to next? Based on the systematically derived evidence provided by Pelland-Marcotte et al, ${ }^{12}$ the fact that more studies focusing on thromboprophylaxis in children with cancer are urgently required is obvious. Apart from widening the cancer settings to cover cancers other than ALL that affect children, prospective studies should focus on thromboprophylaxis strategies for which there is some evidence and knowledge in children, such as LMWH and VKA. This knowledge can lead to possible consideration of novel therapeutic strategies, for example, NOACs such as apixaban, which has been shown to be useful in adults with cancer. ${ }^{15}$ It is up to us as medical researchers and clinicians, funding bodies and the pharmaceutical industry to unite in recognising children as children and not as little adults, and to afford the utmost care and focus to the most vulnerable individuals of our population.

\section{Conflict of Interest}

None declared.

\section{References}

1 Grilz E, Posch F, Königsbrügge O, et al. Association of platelet-tolymphocyte ratio and neutrophil-to-lymphocyte ratio with the risk of thromboembolism and mortality in patients with cancer. Thromb Haemost 2018;118(11):1875-1884

2 Aharon A, Sabbah AR, Issman L, et al. Effects of low- and high-dose chemotherapy agents on thrombogenic properties of extracellular vesicles derived from breast cancer cell. Thromb Haemost 2018;118(03):480-489

3 Carmona-Bayonas A, Jimenez-Fonseca P, Garrido M, et al. Multistate models: accurate and dynamic methods to improve predictions of thrombotic risk in patients with cancer. Thromb Haemost 2019;119 (11):1849-1859

4 Potpara TS, Poposka L. The challenge of thromboprophylaxis in cancer patients - balancing the thrombotic and bleeding risks. Thromb Haemost 2018;118(08):1347-1349

5 Attard C, van der Straaten T, Karlaftis V, Monagle P, Ignjatovic V. Developmental hemostasis: age-specific differences in the levels of hemostatic proteins. J Thromb Haemost 2013;11(10):1850-1854

6 Monagle P, Barnes C, Ignjatovic V, et al. Developmental haemostasis. Impact for clinical haemostasis laboratories. Thromb Haemost 2006;95(02):362-372 
7 Ignjatovic V, Ilhan A, Monagle P. Evidence for age-related differences in human fibrinogen. Blood Coagul Fibrinolysis 2011;22 (02):110-117

8 Yip C, Ignjatovic V, Attard C, Monagle P, Linden MD. First report of elevated monocyte-platelet aggregates in healthy children. PLoS One 2013;8(06):e67416

9 Yip C, Linden M, Attard C, Monagle P, Ignjatovic V. Platelets from children are hyper-responsive to activation by thrombin receptor activator peptide and adenosine diphosphate compared to platelets from adults. Br J Haematol 2015;168(04):526-532

10 Mousa SA, Mohamed S. Inhibition of endothelial cell tube formation by the low molecular weight heparin, tinzaparin, is mediated by tissue factor pathway inhibitor. Thromb Haemost 2004;92 (03):627-633
11 Karlaftis V, Attard C, Monagle P, Ignjatovic V. Latent antithrombin levels in children and adults. Thromb Res 2013;131(01):105-106

12 Pelland-Marcotte MC, Tolea S, Pechlivanogloub P, Brandao LR. Effectiveness and safety of primary thromboprophylaxis in children with cancer: a systematic review of the literature and network meta-analysis. Throm Haemost 2019;119(12):2034-2042

13 Schwarzer G, Carpenter JR, Rücker G. Meta-analysis with R. Cham, Switzerland: Springer; 2015

14 Piovesan D, Attard C, Monagle P, Ignjatovic V. Epidemiology of venous thrombosis in children with cancer. Thromb Haemost 2014;111(06):1015-1021

15 Carrier M, Abou-Nassar K, Mallick R, et al; AVERT Investigators. Apixaban to prevent venous thromboembolism in patients with cancer. N Engl J Med 2019;380(08):711-719 